Vol. 24, No. 1, Januari 2021, hlm. 28-37

p-ISSN: 1410-9344; e-ISSN: 2549-5631

WARTA LPM

homepage: http://journals.ums.ac.id/index.php/warta

\title{
Pelatihan Jurnalistik di SMA Negeri Gondangrejo Kabupaten Karanganyar, Jawa Tengah
}

\author{
${ }^{1}$ Betty Gama dan ${ }^{2}$ Henny Sri Kusumawati \\ ${ }^{1.2}$ FISIP Universitas Veteran Bangun Nusantara Sukoharjo \\ Email: 1'bettygama_62@ymail.com, ${ }^{2}$ henny.sk83@gmail.com
}

\section{Article Info}

Submitted: 20 January 2020

Revised: 27 March 2020

Accepted: 09 May 2020

Published: 12 December 2020

Keywords: Journalistic training, school magazines, SMA
Kata kunci: Pelatihan jurnalistik, majalah sekolah, SMA

\begin{abstract}
Gondangrejo SMA Negeri at Karanganyar currently does not have communication and information media between teachers, students and parents of students in the form of school magazines. Therefore journalism lessons have not been taught to students. Based on these problems, it is necessary to hold journalistic training for Gondangrejo SMA Negeri students. Through journalistic training will greatly assist students in honing their creativity and talent. Based on these problems, the solution offered is to provide journalistic training with the material such as Basics of Journalism, Reporting and Interview Techniques, and Photo Journalism. Theoretically, the trainees are expected to know how the process of making news starts from searching data in the field, packaging and compiling news until the news is suitable for publication. The method used is an explanation of journalism and interview techniques. To find out how far the participants' level of understanding of the training that has been given, therefore pre-test and post-test are first carried out. The specific target of this training is to foster student interest and motivation for the importance of the media to accommodate students'creativity and activities in channeling their talents and self-potential. Based on pre-test and post-test can be seen how far the progress or escalation in knowledge of all participants. There are 4 students in the high category (20\%) in understanding journalism and the rest are in the moderate category (10\%) and low (70\%). But personally each participant has experienced an enhancement from pre-test scores to post-test scores.
\end{abstract}

\section{Abstrak}

SMA Negeri Gondangrejo Karanganyar saat ini belum memiliki media komunikasi dan informasi antara guru, siswa, dan orang tua dalam bentuk majalah sekolah. Hal ini mengakibatkan pelajaran ilmu jurnalistik belum atau tidak diajarkan kepada siswa. Berdasarkan permasalahan tersebut maka perlu diadakan pelatihan jurnalistik kepada siswa SMA Negeri Gondangrejo. Pelatihan jurnalistik sangat membantu siswa dalam mengasah kreativitas dan bakat seseorang. 
Berdasarkan permasalahan tersebut, maka solusi yang ditawarkan adalah dengan memberikan pelatihan. Secara teoritis, peserta pelatihan diharap dapat mengetahui bagaimana proses membuat berita mulai dari pencarian data di lapangan, mengemas dan menyusun berita hingga berita tersebut layak dipublikasikan atau terbit. Metode yang digunakan adalah berupa penjelasan mengenai ilmu jurnalistik. Untuk mengetahui sampai seberapa jauh tingkat pemahaman peserta terhadap pelatihan yang diberikan maka dilakukan pre test dan post test terlebih dahulu. Target khusus pelatihan ini antara lain menumbuhkan minat dan motivasi siswa akan pentingnya media untuk menampung kreativitas dan aktivitas siswa dalam menyalurkan bakat dan potensi diri yang dimiliki. Berdasarkan pre test dan post test dapat diketahui seberapa jauh progres atau peningkatan pengetahuan seluruh peserta. Sebanyak 4 siswa termasuk kategori tinggi (20\%) dalam memahami ilmu jurnalistik dan sisanya 2 siswa termasuk kategori sedang (10\%) dan 14 siswa termasuk kategori rendah (70\%). Tetapi secara personal setiap peserta mengalami peningkatan dari nilai pre test ke nilai post test.

\section{PENDAHULUAN}

Dalam dunia pendidikan, kecerdasan seseorang sangat menentukan keberhasilan dari sebuah proses pendidikan, yang mana orang yang cerdas akan mendapatkan prestasi yang memuaskan. Kecerdasan seseorang tidak bisa datang begitu saja, tetapi perlu dibangun melalui kebiasaan-kebiasaan yang mampu merangsang kecerdasan seseorang, salah satunya adalah baca tulis, yang dalam hal ini bisa dibangun melalui pelatihan jurnalistik. Dengan adanya pelatihan jurnalistik akan sangat membantu peserta dalam mengasah kreativitas dan bakat seseorang, khususnya dalam bidang tulis menulis. Melalui jurnalistik juga mampu membangun daya kritis nalar pelajar dan mahasiswa dalam membaca realitas kehidupan (Building, 2015)

Sekolah merupakan suatu lembaga yang dirancang khusus untuk pengajaran para murid/ siswa di bawah pengawasan para guru. Tujuan dari sekolah adalah mengajarkan anak untuk menjadi anak yang mampu memajukan bangsa. Tingkatan sekolah dimulai dari tingkat SD hingga perguruan tinggi. Sekolah yang dijadikan program pengabdian kepada masyarakat ini adalah SMA Negeri Gondangrejo Karanganyar. SMA Negeri Gondangrejo terletak di Jalan Raya Solo-Purwodadi Km. 11 Gondangrejo Kabupaten Karanganyar, Jawa Tengah. SMA Negeri Gondangrejo berdiri dengan satus kepemilikan
Pemerintah dan berdiri berdasarkan SK Pendirian Sekolah No. 291/0/1999. SMA Negeri Gondangrejo pada tahun ajaran 2018/2019 memiliki 558 siswa, 47 guru dan 20 jumlah kelas. Di SMA ini terdapat tiga jurusan yaitu IPA, Bahasa Indonesia dan Bahasa Inggris.

SMA Negeri Gondangrejo Karanganyar belum memiliki majalah sekolah, sehingga hal ini mengakibatkan pelajaran ilmu jurnalistik tidak atau belum diberikan kepada siswa. Bertitik tolak dari hal tersebut maka tim pengabdian kepada masyarakat memberikan pelatihan dengan maksud memberikan edukasi tentang jurnalistik kepada siswa dan menumbuhkan jiwa jurnalis yang selalu mengedepankan profesionalisme serta kebenaran dalam merangkum sebuah berita.

Konsep dasar dari jurnalistik adalah sesuatu yang berhubungan dengan dunia tulis menulis. Semua aktivitas tulis menulis, baik itu menulis untuk media massa, menulis dalam catatan harian, menulis buku, menulis naskah pidato, dan lainnya, merupakan aktivitas jurnalistik. Hal tersebutsesuai dengan pengertian kata dasar dari jurnalistikitu sendiri, yakni acta diurna (Romawi) yang memiliki arti catatan harian (Hidayatullah, 2016). Produk jurnalistik yang disampaikan melalui media massa, memiliki manfaat bagi audiens untuk mendidik (to educate), menghibur (to entertain), mempengaruhi (to influence), 
dan menyampaikan kritik sosial (social control). Berita sama dengan NEWS (North, East, West dan South), artinya bahwa berita itu di mana-mana. Semua yang ada di dalam adalah berita, tetapi tidak semua yang ada itu bisa dijadikan berita, hanya fenomena yang memiliki nilai berita yang bisa dijadikan berita.

Majalah merupakan media komunikasi massa cetak kedua setelah surat kabar yang banyak dikonsumsi masyarakat. Karakteristik majalah terbit secara mingguan, dua mingguan, bahkan bulanan. Secara perspektif umum, hampir tidak mungkin majalah bisa bersaing dengan surat kabar dan televisi yang selalu menyampaikan informasi setiap hari. Tetapi realitasnya sampai sekarang majalah tetap bertahan. Apa yang membuat majalah tetap bertahan? Menurut Biagi, majalah menyuguhkan informasi yang tidak disampaikan media lain, dan majalah menyuguhkannya dengan lebih lengkap dan mendalam. Kedua, majalah tidak dikonsumsi secara umum, hanya sebagian orang saja yang menjadikan majalah sebagai sumber informasi. Ketiga, majalah adalah produk yang sangat pribadi, majalah merupakan media cetak yang intim dengan pembacanya karena isi majalah tersegmentasi sesuai dengan kondisi psikis, usia, pekerjaan, pendapat, hobi, dan pengetuan/pendidikan seseorang (Biagi, 2010). Mengingat SMA Negeri Gondangrejo belum memiliki majalah sekolah maka pelatihan ini diharapkan dapat mendorong timbulnya motivasi untuk menerbitkan kembali majalah sekolah.

Majalah merupakan penerbitan berkala yang berisi bermacam-macam artikel mengenai topik populer yang terjadi dalam masyarakat dan yang ditujukan pula kepada masyarakat (Hidayatullah, 2016). Sedangkan majalah sekolah yaitu majalah yang diterbitkan oleh sekolah dan berisi tentang aktivitas sekolah. Majalah sekolah merupakan salah satu bentuk media yang membantu siswa meningkatkan keterampilan berbahasanya, terutama bacatulis. Majalah sekolah dapat dijadikan sebagai media komunikasi dan informasi bagi guru dan murid serta orang tua murid. Menurut Kurniawan (1995), majalah adalah penerbitan berkala (bukan harian) yang terbit secara teratur dan sifat isinya tidak menampilkan pemberitaan atau sari berita melainkan berupa artikel atau bersifat pembahasan yang menyeluruh dan mendalam. Majalah sekolah pada umumnya lebih banyak berisi pendapat, baik berupa artikel, pengetahuan, tajuk rencana, surat pembaca dan sebagainya. Jarang sekali ditemui berita yang aktual di majalah sekolah, karena waktu terbit yang periodesasinya terlalu lama (lebih dari satu bulan). Jika ada berita di majalah sekolah, umumnya berupa feature (human interest news). Majalah sekolah adalah terbitan berkala yang sasarannya orang-orang di sekolah, seperti siswa, guru serta pegawai, termasuk orang tua siswa serta lingkungan di sekitar sekolah.

Fungsi media sekolah yaitu sebagai sarana pengembangan diri. Terjun dalam bidang jurnalistik akan membuat seseorang menjadi peka terhadap segala permasalahan yang ada karena dituntut untuk menyikapinya secara kritis sehingga tidak menerima informasi apa adanya (Trimansyah, 2010). Kegiatan ekstrakulikuler ini diharapkan mampu memberikan life skill(kecakapan hidup) kepada siswa. Sebagai media informasi cetak majalah sekolah diharapkan mampu memberikan ide dan gagasan-gagasan cerdas dalam upaya-upaya menunjang kemajuan visi dan misi sekolah yang ingin selalu berprestasi baik dibidang akademik maupun non akademik di era global. Ekstrakurikuler adalah kegiatan non pelajaran formal yang dilakukan peserta didik umumnya di luar jam belajar kurikulum standar. Kegiatan ekstrakurikuler di sekolah memiliki beberapa fungsi, antara lain fungsi pengembangan, fungsi sosial, dan fungsi rekreatif. Pada umumnya siswa akan memilih kegiatan ini sesuai dengan hobi atau kesenangannya. Terkait dengan ekstra kurikuler jurnalistik, banyak keuntungan yang dapat diraih oleh siswa, antara lain siswa mendapatkan ilmu kepenulisan, siswa mampu menulis berita, dan melatih siswa berbaur dengan banyak orang (Aprilia, 2018)

Permasalahan khusus yang terdapat pada SMA Negeri ini adalah kurangnya pengetahuan yang berkaitan dengan pengetahuan ilmu jurnalistik. Maka dengan diadakannya pelatihan membuat berita pada media cetak diharapkan akan menimbulkan dampak untuk menerbitkan majalah sekolah atau setidak-tidaknya dapat dijadikan wacana untuk menerbitkan majalah 
sekolah. Terkait tentang majalah sekolah, artikel yang ditulis Triyono (2016) antara lain menjelaskan, mereka yang dahulunya hanya mengambil informasi di internet untuk majalah dinding, sekarang mereka dapat melakukan pengumpulan berita secara mandiri dan menghasilkan tulisan yang memiliki news value.

Melihat pada permasalahan tersebut maka sangat penting dilakukan pelatihan menulis berita di media cetak. Sesuai dengan tugas utamanya, jurnalistik adalah meliput dan menuliskan fakta di lapangan, perisiwa, realitas sosial dan fenomena menejadi berita. Melalui pelatihan jurnalistik diharapkan peserta dapat memahami bagaimana suatu berita di kemas dan diberitakan melalui media. Pelatihan ini sifatnya hanya transfer pengetahuan dan belum sampai pada aksi untuk melakukan praktik membuat berita, oleh karena itu sifatnya hanya teoritis semata. Oleh karena itu tujuan kegiatan ini yaitu untuk memberikan pelatihan menulis berita di media cetak agar siswa dapat mengetahui, memahami dan mengerti dasar-dasar ilmu jurnalistik sebagai salah satu bentuk dalam proses membuat berita

Pelatihan menulis berita di media cetak ini diharapkan dapat memberi manfaatbagi peserta antara lain:

a. Siswa dapat mengetahui, memahami dan mengerti dasar-dasar jurnalistik

b. Siswa memiliki pengetahuan tentang teknik jurnalistik, teknik reportase, teknik wawancara, dan jurnalistik foto.

c. Siswa mengetahui dan memahami jurnalistik media cetak sehingga kedepan siswa diharapkan dapat mengelola majalah sekolah.

Selain itu target khusus yang diharapkan dari kegiatan pelatihan ini adalah:

a. Bertambahnya keterampilan kerja dan berkembangnya sifat kreativitas dan inovatif siswa untuk bergerak di bidang jurnalistik media cetak

b. Menumbuhkan minat dan motivasi siswa akan pentingnya media untuk menampung kreativitas dan aktivitas siswa dalam menyalurkan bakat dan potensi diri yang dimiliki. c. Kegiatan pelatihan diharapkan dapat memberikan motivasi kepada pihak sekolah untuk memiliki atau menerbitkan majalah sekolah. Dengan terbitnya majalah sekolah maka aktivitas siswa akan bertambah sehingga dapat memberikan nilai plus bagi sekolah.

\section{METODE PELAKSANAN}

Kegiatan yang dilakukan berupa sosialisasi dan pelatihan jurnalistik media cetak. Kegiatan telah dilaksanakan pada tanggal 7 September 2019. Kegiatan pelatihan di buka oleh Kepala Sekolah SMA Negeri Gondangreja yaitu Bapak Hasta, M.Pd. dengan didampingi guru Ibu Siwi Rudatin, M.Pd. dan diikuti sebanyak 20 siswa. Dalam sambutannya, kepala sekolah menyambut baik kegiatan pengabdian yang dilakukan oleh Univet Bantara Sukoharjo. Alokasi waktu kegiatan dibagi menjadi 3 sesi dengan rincian: Sesi pertama, berupa pemaparan mengenai dasar-dasar jurnalistik dengan materi berupa menulis berita dengan rumus $5 \mathrm{~W}+1 \mathrm{H}$, jenis-jenis berita, konstruksi berita. Sesi kedua, pelatihan teknik reportase dan teknik wawancara, dengan materi bahasan mengenai persiapan liputan dan narasumber yang berkompeten, perisapan wawancara, bentuk wawancara dan interview guide. Sesi ketiga berupa pelatihan foto jurnalistik dengan materi berisi penjelasan mengenai foto jurnalistik dan jenis-jenis foto jurnalistik. Metode pelaksanaan kegiatan Jurnalistik Majalah Sekolah SMA Negeri Gondangrejo Karanganyar dapat dijelaskan dalam bagan 1 .

SMA Negeri Gondangrejo Karanganyar belum memiliki majalah sekolah dan hal ini menyebabkan banyak siswa yang belum memahami bagaimana mengelola majalah sekolah. Oleh karena itu guna mengatasi permasalahan tersebut maka solusi yang ditawarkan yaitu memberikan pengetahuan dan keterampilan tentang dasar-dasar jurnalistik, memberikan pengetahuan dan keterampilan teknik reportase dan teknik wawancara, dan memberikan pengetahuan mengenai jurnalistik media foto. 


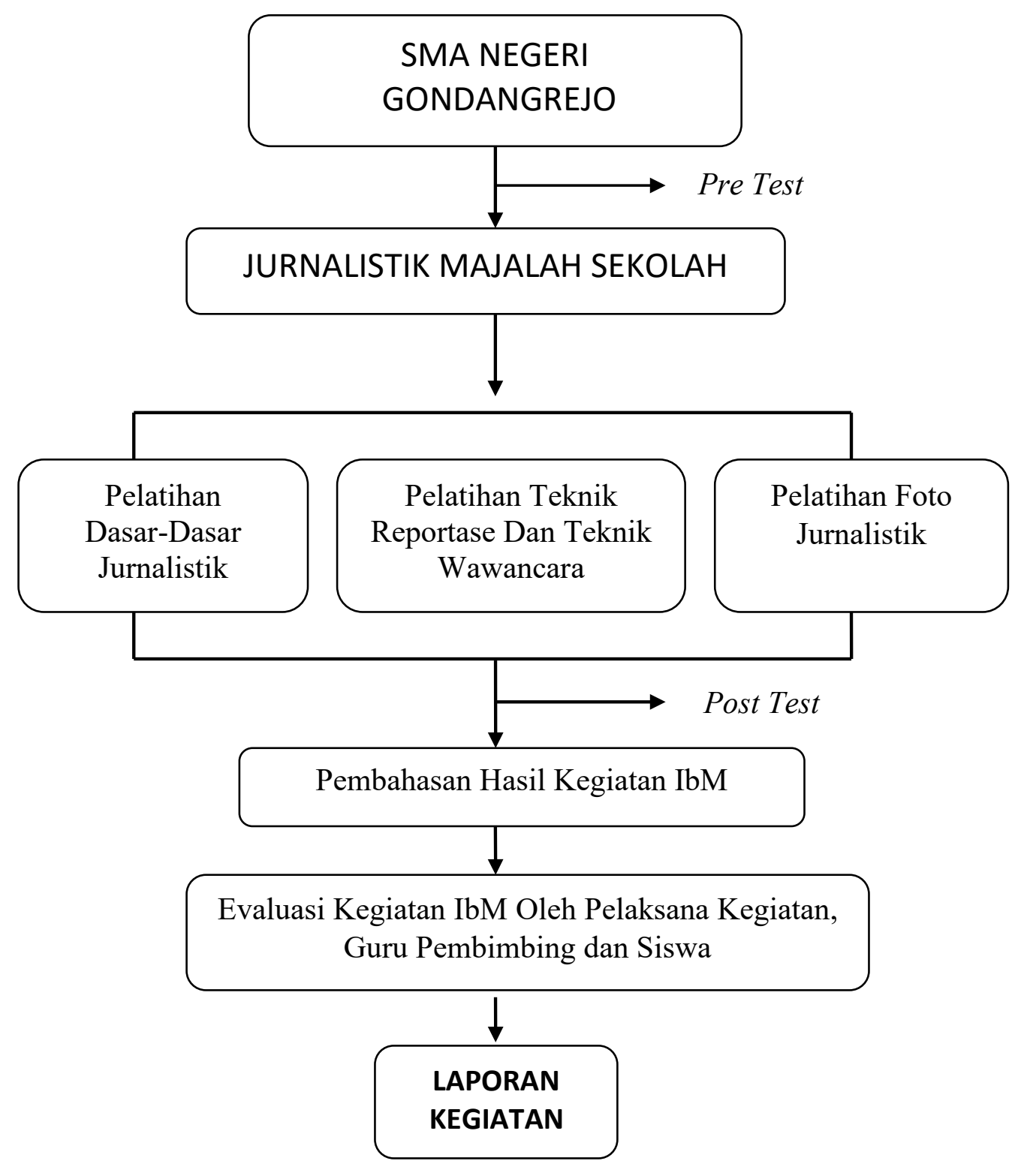

Bagan 1. Metode Pelaksanaan IbM

Meskipun belum memiliki majalah sekolah, maka target khusus pelatihan jurnalistik ini diharapkan dapat menambah keterampilan dan berkembangnya sifat kreativitas dan inovatif siswa untuk bergerak di bidang jurnalistik media cetak, menumbuhkan minat dan motivasi siswa akan pentingnya majalah sekolah sebagai media kreativitas dan aktivitas siswa dalam menyalurkan bakat dan potensi diri yang dimiliki, dan diharapkan dapat memberikan motivasi kepada pihak sekolah untuk mendirikan atau menerbitkan kembali majalah sekolah yang dahulu sempat terhenti. Dengan terbitnya majalah sekolah maka aktivitas siswa akan bertambah sehingga dapat memberikan nilai plus bagi sekolah.
Setelah kegiatan selesai, diadakan evaluasi terhadap kegiatan pelatihan jurnalistik. Metode evaluasi yang digunakan adalah dengan menggunakan pre test dan post test. Hasil dari pretest dan posttest digunakan sebagai dasar untuk mengetahui sampai seberapa jauh tingkat pemahaman siswa terhadap pelatihan jurnalistik yang telah diberikan. Kegiatan ini dilakukan oleh dua orang dosen sebagai ketua pelaksana dan anggota, serta dibantu oleh dua orang mahasiswa. Adapun ketua pelaksana memiliki tugas untuk bertanggungjawab terhadap pelaksanaan dan pemantauan kegiatan pelatihan menulis berita, menyusun proposal, menyampaikan materi pelatihan, membuat laporan hasil pelatihan dan melakukan komunikasi dengan mitra atau 
pihak sekolah. Sedangkan anggota pelaksana bertugas membantu dalam segi administrasi, menyampaikan materi pelatihan, membantu keberlangsungan acara pelatihan. Pelaksana kegiatan pelatihan ini juga bekerja sama dengan Majalah Larise. Kerja sama dengan pihak luar dimaksudkan agar peserta pelatihan mendapat pengalaman belajar dari orang yang berkompeten dibidangnya dan disamping itu guna menambah kepercayaan peserta terhadap pelaksanaan tersebut. Hadir dalam kegiatan pelatihan ini yaitu wartawan Larise dengan materi teknik reportase dan teknik wawancara.

\section{HASIL DAN PEMBAHASAN}

Pelatihan ini dilaksanakan pada hari Sabtu, 07 September 2019 bertempat di SMA Negeri Gondangreja. Jumlah peserta dalam pelatihan ini sebanyak 20 siswa, terdiri dari Kelas X-IPS dan Kelas XI-IPA. Kegiatan yang berlangsung selama satu hari ini dengan metode pembelajaran interaktif sehingga peserta dapat melakukan praktik langsung berdasarkan pengarahan dari narasumber. Adapun materi kegiatan dapat dijelaskan sebagai berikut.

Pada sesi pertama, ketua pelaksana memaparkan mengenai materi Dasar-Dasar Jurnalistik. Materi ini menekankan pada aspek bagaimana menulis berita yang menarik perhatian pembaca dan bagaimana membuat kontruksi berita sesuai dengan kaidah-kaidah dalam ilmu jurnalistik. Menjelaskan rumus $5 \mathrm{~W}+$ $1 \mathrm{H}$ dan piramida terbalik. Materi ini diharapkan dapat menambah pengetahuan siswa mengenai jurnalistik dan mendorong siswa untuk menulis.

Selanjutnya sesi kedua, materi yang disampaikan berupa teknik reportase dan teknik wawancara. Materi teknik reportase atau liputan ini disampaikan oleh mitra yaitu wartawan Larise Sofyan Yuli, S.Sos. Pokok bahasan berkaitan tentang bagaimana melakukan liputan peristiwa dan menyusun berita dengan menggunakan rumus $5 \mathrm{~W}+1 \mathrm{H}$ sehingga menjadi sebuah berita yang layak dibaca oleh publik.

Materi ini diharapkan menambah pengetahuan siswa bagaimana proses pembuatan berita yang dilakukan oleh wartawan dan bagaimana wartawan mengolah hasil liputan menjadi berita. Wawancara merupakan salah satu cara untuk mendapatkan informasi. Wawancara merupakan percakapan antara dua orang atau lebih dan berlangsung antara narasumber dan pewawancara untuk mendapatkan hasil yang maksimal, maka wawancara perlu dipersiapkan terlebih dahulu baik berkaitan dengan materi yang akan ditanyakan dan juga indentitas narasumber yang akan diwawancarai. Materi ini diharapkan dapat menumbuhkan sikap siswa untuk lebih percaya diri dan berani mengajukan pertanyaan kepada narasumber.

Pada sesi kedua disampaikan oleh anggota tim pelaksana dengan materi Jurnalistik Foto. Materiini membahas jenis-jenis foto jurnalistik, pentingnya foto dalam berita, menulis caption dan sebagainya. Materi ini memberi pemahaman kepada siswa bahwa melalui foto jurnalistik akan memudahkan pembaca untuk memahami berita.

Sebelum dilakukan pelatihan peserta mengisi lembar pre test yang telah disediakan dengan menjawab pertanyaan tertutup. Adapun pertanyaan yang diajukan sebagai berikut:

1. Apa yang dimaksud dengan jurnalistik?

2. Apa arti $5 \mathrm{~W}+1 \mathrm{H}$ dalam teknik penulisan Berita?

3. Apa yang disebut dengan media online?

4. Taukah anda pengertian dari reportase?

5. Taukah anda pengertian dari wartawan?

6. Apa yang dimaksud dengan narasumber?

7. Jelaskan apa yang dimaksud dengan cover majalah!

8. Jelaskan perbedaan surat kabar dan majalah!

9. Jelaskan pengertian anda tentang foto jurnalistik!

10. Sebutkan bentuk-bentuk media massa!

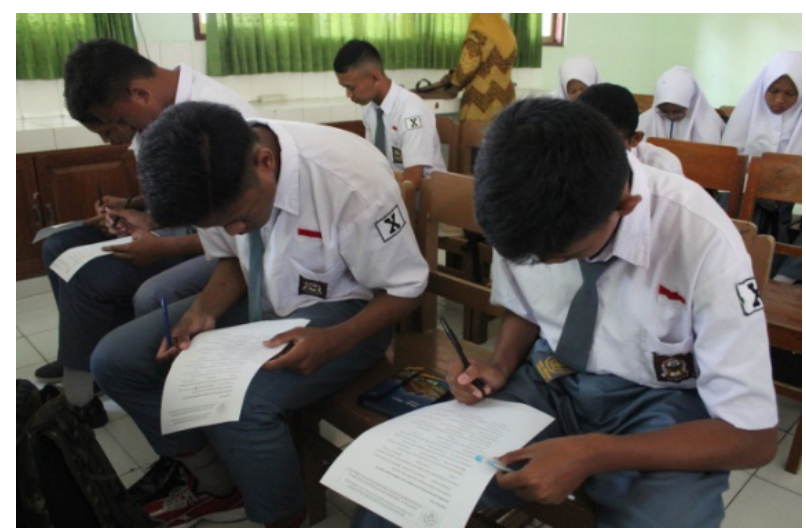

Gambar 1. Peserta Pelatihan

Warta LPM, Vol. 24, No. 1, Januari 2021 
Tujuan dilakukan pre test adalah untuk mengetahui sejauh mana tingkat pemahaman peserta terkait dengan materi sebelum kegiatan dimulai. Pada gambar 1 menunjukkan peserta pelatihan menulis berita di media cetak. Meskipun sekolah belum memiliki majalah sekolah tetapi peserta antusias dalam mengikuti kegiatan. Materi yang diberikan merupakan hal baru bagi mereka. Melalui metode pembelajaran interaktif diharapkan peserta lebih memahami materi yang diajarkan.

Guna memberikan pemahaman bagaimana suatu berita diperoleh maka terlebih dahulu dijelaskan tentang pengertian jurnalistik, Rumus $5 \mathrm{~W}+1 \mathrm{H}$ dan membuat berita dengan menggunakan model piramida terbalik. Selanjutnya diperagakan bagaimana melakukan wawancara dengan narasumber. Untuk keperluan tersebut peserta diminta tampil kedepan melakukan wawancara (Gambar 2).

Efek dari kegiatan pelatihan ini terlihat dari ranah koginitif, yaitu siswa yang tidak mengetahui menjadi mengetahui dan memahami bagaimana proses pembuatan berita. Dari tempat terjadinya peristiwa, melakukan wawancara dan mengolah informasi menjadi berita yang layak dipublikasikan. Kegiatan yang pandu oleh dua orang dosen dan seorang awak media ini menarik perhatian peserta. Hal ini terlihat dari aktivitas pelatihan dengan pertanyaan yang diajukan dan siswa pun dengan senang hati tampil ke depan ketika diminta. Di akhir kegiatan, peserta diminta untuk mengisi lembar post test. Post test dilakukan untuk mengetahui sejauh mana tingkat pemahaman siswa setelah materi pelatihan disampaikan.

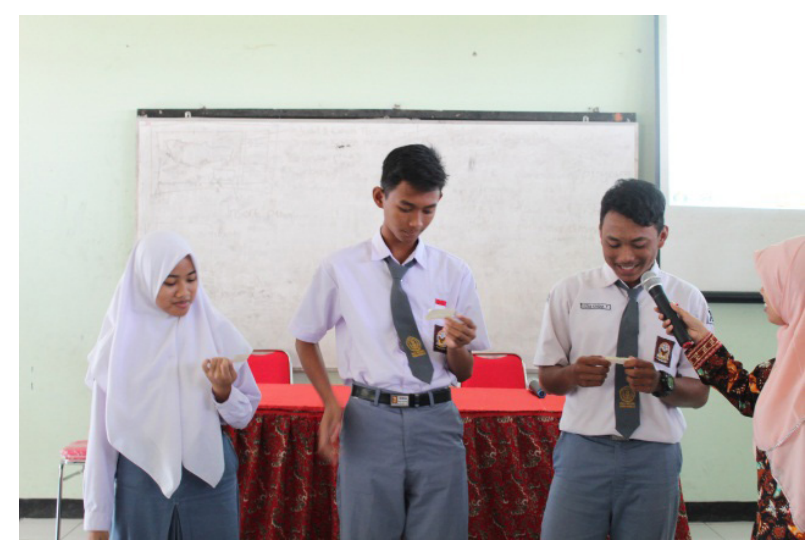

Gambar 2: Praktik wawancara
Berdasarkan hasil pelaksanaan pre test pelatihan menulis berita pada media cetak dapat dijelaskan bahwa siswa belum sepenuhnya memahami pengertian jurnalistik. Terhadap pertanyaan, Apa arti $5 \mathrm{~W}+1 \mathrm{H}$ dalam teknik penulisan Berita? Jawaban siswa menunjukkan score tinggi (139) dibandingkan dengan pertanyaan lainnya. Siswa dapat menjelaskan arti dari kata $5 \mathrm{~W}+1 \mathrm{H}$ yang terdiri dari whowhat-where-when-why dan how. Rumus $5 \mathrm{~W}+$ $1 \mathrm{H}$ merupakan rumus dalam membuat berita yang sering dilakukan oleh wartawan.

Nilai terendah pada pertanyaan pretest ini ketika siswa mengalami kesulitan dalam menjelaskan pertanyaan: Jelaskan pengertian anda tentang foto jurnalistik! Foto jurnalistik merupakan bentuk dari jurnalisme yang menggunakan gambar-gambar dalam rangka mengambarkan sebuah berita. Artikel yang ditulis Ferry Darmawan dengan judul Jurnalistik Foto di Era Digital: Antara Teknologi dan Etika, menjelaskan dalam dunia jurnalistik, foto merupakan kebutuhan yang vital sebab foto merupakan salah satu faktor daya pemikat bagi para pembacanya. Selain itu, foto merupakan pelengkap dari berita tulis (Darmawan, 2005). Foto jurnalistik dapat dimaknai sebagai foto yang dihasilkan atau dibuat oleh seorang jurnalis. Taufan Wijaya menjelaskan foto jurnalistik menghubungkan manusia di seluruh dunia dengan bahasa gambar (Wijaya, 2011)

Secara keseluruhan tingkat pemahaman siswa sebelum pelaksanaa kegiatan dapat dijelaskan sebagai berikut. Siswa yang memahami jurnalistik ada sebanyak 7 orang (35 \%), siswa yang kurang memahami ada 11 orang (55 \%) dan siswa yang tingkat pengetahuan tidak memahami ada 2 orang (10 \%). Rendahnya pengetahuan siswa terhadap ilmu jurnalistik dapat dipahami karena di SMA Negeri Gondangrejo mata pelajarannya kurang atau tidak menyinggung tentang jurnalistik dan selain itu juga belum memiliki majalah sekolah. Oleh karena itu dapat dipahami apabila dari sebanyak 20 siswa hanya sebagian kecil saja yang memahami jurnalistik. Secara keseluruhan nilai pre test menunjukkan nilai 1157 atau rata-rata 57.85 berada pada level rendah dalam memahami ilmu jurnalistik 
Post test yang dajukan setelah selesai pelatihan menunjukkan total nilai dengan jumlah 1325. Hal ini menunjukkan adanya kenaikan tingkat pemahaman dari pre test yang dilakukan dengan jumlah nilai 1157. Nilai terbesar pada post test ini sama dengan pertanyaan pre test yaitu: Apa arti $5 \mathrm{~W}+1 \mathrm{H}$ dalam teknik penulisan Berita? Jawaban siswa menunjukkan score tertinggi (153) dibandingkan dengan jawaban lainnya. Sedangkan nilai terendah ada pada pertanyaan: Apa yang dimaksud dengan jurnalistik? Jawaban siswa menunjukkan jumlah angka 122. Rendahnya nilai pertanyaan jurnalistik dapat dipahami mengingat siswa tidak mendapatkan pelajaran jurnalistik. Menurut Sumardiria, jurnalistik diartikan sebagai kegiatan yang berhubungan dengan pencatatan atau pelaporan setiap hari. Jurnalistik juga bisa dimaknai sebagai ilmu pengetahuan yang berhubungan dengan dunia tulis menulis. Dari penjelasan tersebut dapa disimpulkan bahwa siapapun yang melakukan aktivitas tulis menulis, sesungguhnya dia telah melakukan aktivitas jurnalistik (Sumadiria, 2006)

Berdasarkan penjelasan tersebut maka dalam pelaksanaan post test dapat dibagi menjadi 3 tingkat yaitu memahami, kurang memahami dan tidak memahami. Oleh karena itu siswa yang memahami ilmu jurnalistik ada 8 orang (40\%), siswa yang kurang memahami ada 8 orang (40\%) dan siswa yang tidak memahami ada 2 orang (20\%). Secara keseluruhan nilai post test menunjukkan nilai 1325 atau rata-rata 66.25 berada pada level sedang dalam memahami ilmu jurnalistik

Berdasarkan hasil pre test dapat dijelaskan secara keseluruhan tingkat pengetahuan siswa SMA Negeri Gondangrejo mengenai pelatihan jurnalistik majalah sekolah menunjukkan nilai 1157 atau rata-rata 57,85 \%. Sementara itu nilai post test mengalami peningkatan menjadi 1325 atau $66.25 \%$.

Tabel Perbandingan Pre Test dan Post Test

\begin{tabular}{|c|c|c|c|c|c|}
\hline \multirow{2}{*}{ No. } & \multirow{2}{*}{ Nama } & \multicolumn{2}{|c|}{ Nilai } & \multirow{2}{*}{$\begin{array}{c}\text { Progress } \\
(\%)\end{array}$} & \multirow{2}{*}{ Kategor } \\
\hline & & Pre Test & Post Test & & \\
\hline 1 & Putri Mawardani & 71 & 74 & 4.22 & Rendah \\
\hline 2 & Isnaini Nur H & 61 & 65 & 6.15 & Rendah \\
\hline 3 & Hilda Fitria D & 56 & 64 & 14.28 & Rendah \\
\hline 4 & Shabiya Hasna P & 60 & 65 & 8.33 & Rendah \\
\hline 5 & Adinda N. A. & 55 & 62 & 12.72 & Rendah \\
\hline 6 & Fathurohmah Putri D & 64 & 72 & 12.50 & Rendah \\
\hline 7 & Irmala Taibat Waqiah S. & 45 & 59 & 31.11 & Tinggi \\
\hline 8 & Adelina Damayanti A. & 47 & 62 & 31.91 & Tinggi \\
\hline 9 & Ema Agustin R. & 55 & 57 & 3.64 & Rendah \\
\hline 10 & Wahyu Fanny F. & 33 & 46 & 39.39 & Tinggi \\
\hline 11 & Naiin Maya A. & 51 & 58 & 13.72 & Rendah \\
\hline 12 & Suci Ramadhan & 69 & 74 & 5.80 & Rendah \\
\hline 13 & Fitria Ayu Nashita & 59 & 73 & 23.72 & Sedang \\
\hline 14 & Viona Anggraini & 63 & 69 & 9.52 & Rendah \\
\hline 15 & Oktaviola Wahyu N. & 63 & 71 & 12.70 & Rendah \\
\hline 16 & Zindha Jesica Kama S. & 76 & 84 & 10.53 & Rendah \\
\hline 17 & Talitha Ghea Shafa & 55 & 64 & 16.36 & Sedang \\
\hline 18 & Nadia Rahmawati & 64 & 72 & 12.50 & Rendah \\
\hline 19 & Dias Calysta N. D & 51 & 57 & 11.76 & Rendah \\
\hline \multirow[t]{2}{*}{20} & Desyana Putri S. & 59 & 77 & 30.51 & Tinggi \\
\hline & Jumlah & 1157 & 1325 & & \\
\hline
\end{tabular}


Pada Tabel 1 di atas menunjukkan progres pelatihan setelah diadakan pre test dan post test. Sebanyak 4 siswa (20\%) termasuk kategori tinggi, kategori sedangkan ada 2 siswa (10\%) dan kategori rendah ada 14 siswa (70\%). Lebih lanjut dapat dijelaskan secara personal semua siswa mengalami progress atau peningkatan setelah dilakukan post tes. Tetapi setelah dilakukan perhitungan keseluruhan peserta ternyata progress siswa tidak mengalami kenaikan yang signifikan. Misal Ema Agustin R. mengalami progress sebesar 3.64\% dengan kategori rendah sedangkan Wahyu Fanny F. dengan progres 39.39\% dengan kategori tinggi.

Berdasarkan pengamatan selama pelatihan menunjukkan bahwa peserta sangat antusias sekali mengikuti pelatihan menulis berita jurnalistik di media cetak. Hal tersebut ditunjukkan melalui aktivitas peserta yang penuh semangat mengikuti kegiatan dan pengajuan pertanyaan kepada narasumber sehingga kegiatan menjadi lebih hidup dan interaktif. Meskipun kegiatan hanya berlangsung selama 1 hari $(7$ September 2019) tetapi minat siswa untuk mengetahui dan memahami ilmu jurnalistik sangat tinggi. Kehadiran majalah sekolah sebenarnya juga diharapkan siswa karena dapat dijadikan media untuk melakukan ekspresi diri menyalurkan bakat, belajar berorganisasi, gotong-royong dan saling menghargai. Kegiatan pengabdian kepada masyarakat ini diapresiasi baik oleh kepala sekolah SMA Negeri I Gondangrejo, Hasto Tyas Harjadi, S.Pd., M.Pd. yang kemudian mengatakan, kegiatan ini bermanfaat bagi siswa sesuai komitmen dari sekolah membekali siswa tidak hanya sekedar teori tetapi juga praktik terutama bagaimana berbicara dihadapan orang banyak. Terkait majalah sekolah semoga kedepannya ada tindaklanjutnya dapat bermanfaat bagi siswa maupun sekolah.

Akhir dari pelatihan ini diharapkan mampu menumbuhkan motivasi dari pihak sekolah untuk menerbitkan majalah sekolah. Hingga artikel ini dibuat pihak sekolah belum menindaklanjuti penerbitan majalah sekolah karena masih dalam wacana. Meskipun internet penuh dengan big data yang dapat diakses kapan saja dan di mana saja tetapi kehadiran majalah sekolah selalu diharapkan karena merupakan media komunikasi yang sangat berguna bagi guru, siswa dan orang tua siswa. Bill Gates pernah mengatakan bahwa pada 2000 bisnis media massa cetak akan mati. Apakah terbukti? Memang apa yang dikatakan Bill Gates tidak sepenuhnya salah, sebab banyak juga penerbitan media cetak yang tumbang satu persatu, tetapi tidak sedikit yang masih bertahan dan berkembang. Lalu mengapa masyarakat masih mempercayai media cetak sebagai sumber informasi? Berarti masih ada hal yang dibutuhkan masyarakat yang dimiliki media cetak dibandingkan media lainnya. Misalnya, media cetak dapat menyediakan berita mendalam yang tidak dapat diberitakan oleh televisi dan hasil dari media cetak dapat dijadikan alat bukti, seperti kupon, formulir dan sejenisnya yang tidak bisa diberikan oleh siaran televisi (Hidayatullah, 2015).

\section{SIMPULAN}

Setelah dilakukan pelatihan membuat berita pada media cetak, dapat diambil simpulan sebagai berikut:

Pengetahuan peserta pelatihan menulis berita di media cetak sangat terbatas sekali. Hal ini terlihat dari hasil evaluasi yang dilakukan menunjukkan hasil yang signifikan. Progres atau peningkatan pengetahuan setelah dilakukan sangat rendah terhadap keseluruhan peserta. Terlihat hanya sebanyak 4 siswa termasuk kategori tinggi (20\%) dalam memahami ilmu jurnalistik dan sisanya termasuk kategori sedang (10\%) dan rendah (70\%). Tetapi secara personal setiap peserta mengalami peningkatan dari nilai pre test ke nilai post test.

\section{UCAPAN TERIMA KASIH}

Ucapan terima kasih kami sampaikan kepada LPPM Universitas Veteran Bangun Nusantara Sukoharjo atas kesediaannyadalam pelaksanaan kegiatan ini. Selanjutnya ucapan terima kasih kami sampaikan kepada seluruh peserta yang telah mengikuti pelatihan dan pihak lain yang telah membantu pelaksanaan kegiatan ini. 


\section{DAFTAR PUSTAKA}

Aprilia, E. (2018). Ekskul Jurnalistik Picu Keterampilan Menulis Siswa. Radarsemarang.com. 19 May 2018. Retrieved from https://radarsemarang.com/2018/05/19/ekskul-jurnalistik-picuketerampilan-menulis-siswa/

Biagi, S. (2010). Media/Impact Penganar Media Massa. Jakarta: Salemba Humanik.

Building, M. (2015). Pelatihan Jurnalistik Untuk Kaum Muda. Jakarta, 28 November 2015. Retrieved from https://mikobuilding.wordpress.com/2015/10/28/pelatihan-jurnalistik-untuk-kaum-muda/

Darmawan. (2005). Jurnalistik Foto di Era Digital: Antara Teknologi dan Etika. Mediator Vol. 6 No. 1, Juni 2005.

Hidayatullah, A. (2016). Jurnalisme Cetak, Konsep dan Praktik (p. 179). p. 179. Yogyakarta: Buku Litera.

Kurniawan, J. (1995). Rahasia Dapur Majalah di Indonesia. Jakakarta: Gramedia.

Sumadiria, A. H. (2006). Jurnalistik Indonesia Menulis Berita dan Features. Panduan Praktis Jurnalistik Profesional. Bandung: Simbiosa Rekatama Media.

Trimansyah, B. (2010). Jurnalistik untuk Remaja: Buku Pintar Wartawan Sekolah (Edisi Revisi). Bandung: PT Remaja Karya.

Triyono, A. (2016). Peningkatan Kapasitas Wartawan Siswa Dalam Penerbitan Majalah Sekolah Di SMP Muhammadiyah PK Al-Kautsar Kartasura. Surakarta: Jurnal Warta LPPM Volume 19, No. 2 September 2016.

Wijaya, T. (2011). Foto Junalistik dalam Dimensi Utuh. Klaten: Sahabat. 